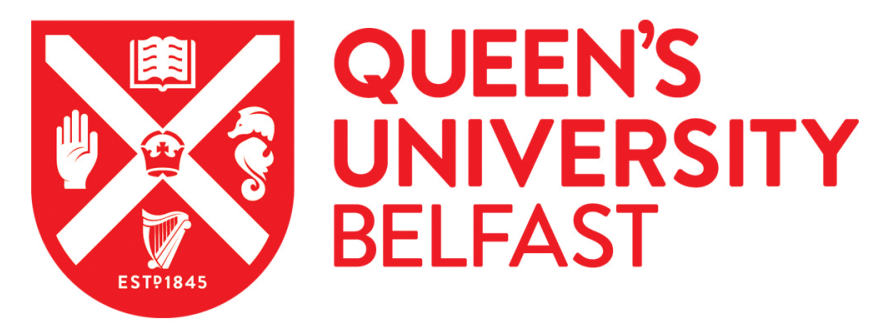

\title{
The role of dispersal and local environment in urban land snail 5 assemblages: an example of three cities in Central Italy
}

\author{
Barbato, D., Benocci, A., Caruso, T., \& Manganelli, G. (2017). The role of dispersal and local environment in \\ urban land snail 5 assemblages: an example of three cities in Central Italy. Urban Ecosystems. \\ https://doi.org/10.1007/s11252-017-0643-8
}

\section{Published in:}

Urban Ecosystems

\section{Document Version:}

Peer reviewed version

Queen's University Belfast - Research Portal:

Link to publication record in Queen's University Belfast Research Portal

Publisher rights

(C) 2017 Springer Science+Business Media New York

The final publication is available at Springer via http://dx.doi.org/10.1007/s11252-017-0643-8

\section{General rights}

Copyright for the publications made accessible via the Queen's University Belfast Research Portal is retained by the author(s) and / or other copyright owners and it is a condition of accessing these publications that users recognise and abide by the legal requirements associated with these rights.

Take down policy

The Research Portal is Queen's institutional repository that provides access to Queen's research output. Every effort has been made to ensure that content in the Research Portal does not infringe any person's rights, or applicable UK laws. If you discover content in the Research Portal that you believe breaches copyright or violates any law, please contact openaccess@qub.ac.uk. 
1 The role of dispersal and local environment in urban land snail assemblages: an example of three cities in central Italy

Debora Barbato, ${ }^{*}{ }^{*}$ Andrea Benocci, ${ }^{1}$ Tancredi Caruso, ${ }^{2}$ Giuseppe Manganelli ${ }^{1}$

9 1'Dipartimento di Scienze Fisiche, della Terra e dell'Ambiente, Università di Siena, Via Mattioli 4, 53100 Siena, Italy $10{ }^{2}$ School of Biological Sciences and Institute for Global Food Security, Queen’s University Belfast, 97 Lisburn Road, 11 Belfast BT9 7BL, Northern Ireland

12

13 *Corresponding author:

14 Debora Barbato, e-mail debora.barbato87@gmail.com; phone number +390577232920; fax +390577232896

15

16 Keywords: urban biodiversity, terrestrial invertebrates, environment, spatial filters, variation partitioning

Acknowledgments: Riccardo D’Orazio helped during field work; Folco Giusti, Leonardo Favilli and Emilia Rota made 19 constructive comments and criticisms.

20

21 
22 Abstract Ecologists increasingly appreciate the central role that urban biodiversity plays in ecosystems, however much 23 urban biodiversity is neglected, especially some very diverse groups of invertebrates. For the first time in southern 24 Europe, land snail communities are analysed in four urban habitats along a geographical gradient of three cities, using 25 quantitative methods and assessing the relative roles of local environmental conditions (“distance from sea”, "distance 26 from city centre", "vegetation cover") and spatial effects by principal coordinate analysis of neighbour matrices, 27 redundancy analysis and variation partitioning. A total of 53 species was recorded, a richness similar to that of natural 28 areas. At habitat level, species richness did not show a clear increasing trend from more to less urbanized habitats, but 29 rather a homogeneous pattern. At city level, study areas hosted rather heterogeneous species assemblages and biotic 30 homogenization did not seem to have any impact; thus, only three species could be considered alien. Variation 31 partitioning showed that land snail communities were mostly structured by environmental factors, even when spatial 32 structures independent of measured environmental variables were included: "vegetation cover" and "distance from city 33 centre" were the environmental variables that explained most of the variation in species composition. The lack of strong 34 spatial structure also unexpectedly suggested that transport by humans aids dispersal of organisms with low mobility, 35 which are usually limited by spatial constraints in natural environments. These results provide ecological and 36 conservation implications for other invertebrate groups, suggesting to set priorities in management strategies that 37 include habitat conservation at local scale. 
Nowadays more than half the world's population lives in large urban settlements. This percentage is predicted to increase to 66\% by 2050 (United Nations 2014). Although it is the most common human habitat (Grimm et al. 2008), the urban environment has been neglected by researchers (Maurer et al. 2000; Beninde et al. 2015; Hartop et al. 2015) as unnatural and poor in biodiversity (Grimm et al. 2008; Paul and Meyer 2008; Güneralp and Seto 2013), besides being subject to biotic homogenization due to the increasing number of non-native species (Lockwood 2004; McKinney 2006; La Sorte et al. 2007; Williams et al. 2009) and habitat fragmentation (McKinney 2002; Cadenasso et al. 2007). While urbanization is certainly a major cause of biodiversity and habitat loss (Czech et al. 2000; McKinney 2006; Grimm et al. 2008; Hahs et al. 2009), the influence of urban land use on biodiversity is more complex than expected (McKinney 2008).

In recent years, the belief that cities only affect the surrounding environment negatively has been challenged. An increasing body of literature has investigated urban biodiversity (Beninde et al. 2015), covering groups such as birds, invertebrates, plants and even zooplankton (Mimouni et al. 2015). Surprisingly, researchers are discovering that cities can protect and control vulnerable and particular ecosystems (UNEP 2005), as well as high levels of biodiversity (Aronson et al. 2014) including native species (Barratt et al. 2015), sometimes showing the same dynamic interactions as in nature (Baldock et al. 2015; Beninde et al. 2015). Studies have revealed the extreme ecological importance of particular urban habitats for species dispersal (Angold et al. 2006). Moreover, urban green areas can have a positive influence on human quality of life (Fuller et al. 2007; Mitchell and Popham 2008; Carrus et al. 2015; Taylor and Hochuli 2015) in terms of recreation and public participation in scientific activities (Beumer and Martens 2015).

Although interest in urban ecology is increasing, not much is yet known about less charismatic invertebrates such as land snails. This is surprising because according to the IUCN Red List, molluscs are the group most subject to extinctions, which often go completely unnoticed (Lydeard et al. 2004; Régnier et al. 2009). The current lack of scientific documentation and their low mobility make land snails susceptible to anthropogenic disturbance and habitat fragmentation (Douglas 2011). Malacofauna currently includes several rare and endangered species, and constitutes $20 \%$ of all threatened animals and 37\% of known animal extinctions since the year 1600 (Seddon 1998). Land snails are numerous and diverse; they live in almost all terrestrial environments and play a key role in worldwide trophic webs (Baur and Baur 1993; Douglas et al. 2013). Snails are preyed on by a wide range of animals from insects to salamanders, toads, lizards, snakes, birds and mammals. Some species of fireflies (i.e. Pyrocoelia pectoralis, Cratomorphus spp.) feed mainly on land snails (Viviani 2001; Wang et al. 2007). Many birds require a huge quantity of calcium carbonate for the formation of eggshells, relying on land snails for Ca supplementation (Mänd et al. 2000). Their low mobility makes snails, who also have good bioaccumulation capacity (Pauget et al. 2013), perfect bioindicators of environmental quality (Cuttelod et al. 2011; Rota et al. 2016).

Studies on urban ecology are often descriptive checklists of traditional biodiversity components, such as richness and diversity measures. Since interactions between communities and their physical environment, and between organisms, occur at precise spatial and temporal scales (Borcard et al. 2004), discovering spatial structures at each scale and the processes involved in their creation is important for understanding the ecological patterns of natural communities (Borcard et al. 2004). In ecology, space has a key role in shaping the distribution of species assemblages, even if it is often neglected. Spatial heterogeneity is often driven by a wide range of factors that interact with each other in different ways (Borcard et al. 1992). The traditional niche-based model assumes that the local environment itself controls the spatial structure of species assemblages: in other words the interaction between a species and its physical 
environment may mould its distribution through adaptation to and interaction with different habitat features (Borcard et al. 2004). According to this model, it is the environment itself, through resource types and habitat conditions, that determines how similar/dissimilar communities are, irrespective of spatial proximity or distance between assemblages (Caruso et al. 2012). Sometimes spatial structures may be generated by species assemblages themselves and can persist despite environmental changes (neutral model) (Hubbell 2001). In this case the space effect is described directly by community dynamics through dispersal limitations, demographic stochasticity or competitive/predatory processes without any environmental influence (Legendre et al. 2009).

Advanced and nowadays well established multivariate techniques such as principal coordinate analysis of neighbour matrices (PCNM) and variation partitioning (ter Braak 1986; Borcard et al. 1992; Legendre and Legendre 1998; Borcard and Legendre 2002; Borcard et al. 2004) have recently made it possible to disentangle and quantify the relative and pure effects of environment and space in shaping variations in community composition ( $\beta$ diversity), as well as the fraction of species variation explained by space and environment together. These techniques provided a useful tool for quantifying the amount of variation uniquely attributable to measured environmental factors, separating it from spatial structures potentially created by unmeasured environmental factors but also population and dispersal dynamics independent of environmental factors (e.g Legendre et al. 2009).

In southern Europe, there has been a complete lack of any quantitative and spatially explicit research into any aspect of urban land snail biodiversity, whereas in central Europe Horsák et al. (2009) and Lososová et al. (2011) have been the only authors to compare plant and land snail diversity in different urban habitats across several cities, using a standardized sampling protocol. Chytrý et al. (2012) subsequently highlighted the importance not only of the environmental but also of the space effect in shaping urban community structure across groups of different sizes and with different dispersal abilities (i.e. subaerial cyanobacteria and algae, vascular plants, land snails, grass, and animaldispersed or wind-dispersed trees and shrubs) in central European cities. Thus we have a major gap in scientific knowledge, since the Mediterranean is one of the world's richest areas in terms of species diversity, but also one of the most threatened, mainly by human impact, especially habitat loss and degradation (Cuttelod et al. 2008). In this geographical context, the extremely complex biogeographical framework of Italy makes it a huge source of biodiversity: with regard to molluscs, the second in Europe, ranking just after Greece in terms of species and subspecies richness (Cuttelod et al. 2011).

Here for the first time, the spatial variation component of urban land snail communities is studied in different habitats along a geographical gradient of three cities in Tuscany (Italy). The aims of the study were: 1) to analyse and compare land snail biodiversity in terms of richness and potential differences in species composition (alpha $\alpha$, beta $\beta$ and gamma $\gamma$ diversity) in four different human habitats along a gradient of three cities in central Italy; 2) to evaluate the presence of species of European Conservation Concern (ECC) and the impact of alien species, if any; 3) to detect factors affecting community structure by partitioning the pure effect of "environment” (measured environmental factors) from that of "space" (unmeasured environmental variation, biotic interactions that structure population spatially even within an environmentally homogeneous habitat and also dispersal limitations), as well as the combined effect, on the distribution of urban land snail communities by means of multivariate variation partitioning.

\section{Materials and methods}

\section{Study area}


We investigated three central Italian cities along a geographical transect about $100 \mathrm{~km} \mathrm{long}$, extending from the Tyrrhenian coast to the Apennine mountain chain (Fig. 1). The cities differ for example in altitude, population and foundation date, but all have old city walls.

Grosseto (altitude $10 \mathrm{~m}$, population 82,284 , area $474 \mathrm{~km}^{2}$ ) is located in southwestern Tuscany, $10 \mathrm{~km}$ from the Tyrrhenian coast. Situated in the alluvial plain of the Ombrone river, the largest plain in southern Tuscany, Grosseto was founded in the High Middle Ages. Its Medicean walls were begun in 1574, replacing those from the 12th-14th centuries. Climate is Mediterranean with mild wet winters and hot dry summers.

Siena (altitude $322 \mathrm{~m}$, population 52,774, area $118 \mathrm{~km}^{2}$ ) is located in central Tuscany and is the highest of the three cities and the one with the smallest population. Founded in Roman times, it has well preserved green areas within its perimeter. The historical centre of Siena, a UNESCO World Heritage Site, is surrounded by medieval walls, which include the Medici fort (1561-1563). Climate is sub Mediterranean with precipitation sufficiently distributed throughout the year, so there is no real dry season.

Arezzo (altitude $296 \mathrm{~m}$, population 99,232, area $386 \mathrm{~km}^{2}$ ) is further east, near the Apennines. It is the oldest of the three, believed to have been one of twelve major Etruscan cities. Climate is continental due to its location straddling the Arno and Chiana valleys at the foot of the Apennines. In the high part of the town the Medicean walls enclose the cathedral, town hall and Medici Fortress.

\section{Sampling design and data collection}

Sampling design included four urban habitat types over a gradient of human impact from heavily affected and disturbed sites to quite well preserved naturalized habitats (Lososová et al. 2011). Google Earth and city maps were used to choose two spatially independent sites for each habitat type in the three areas, making a total of 24 sites. Habitat types were chosen according to the standardized protocol of Lososová et al. (2011) with modifications: 1. WALLS: historical walls of the city centre; 2. PARK: city parks and public gardens with old deciduous trees (tree cover 10-50\%) and frequently mown lawns; 3. E-SUC: early successional sites, strongly disturbed in the last 1-3 years, with a prevalence of bare ground and sparse vegetation cover, usually in or around construction and industrial sites; 4. WOOD: quite well preserved wooded patches, with well-structured vegetation (old and young trees, especially holm oak with scattered shrubs).

A qualitative visual search (presence/absence) was conducted for a standard time of $2 \mathrm{~h}$ at each site. The timeconstrained sampling strategy made it possible to maximize species numbers by including a huge number of heterogeneous microhabitats and environmental conditions. It also avoided logistic problems related to sampling activity on vertical surfaces (city walls), where a common standard-sized plot can be hard to arrange.

In each site, 5 litres of debris and leaf litter was also collected to detect small and very small species (Cameron and Pokryszko 2005). Despite the huge investment in effort and time, this "volume method" combined with visual search produces more information on small species (Menez 2007; Benocci et al. 2015).

The litter was sieved with a $10 \mathrm{~mm}$ mesh, then dried and sieved again with meshes of decreasing size down to 0.5 $\mathrm{mm}$. Specimens were determined at species rank and recorded in a database. The nomenclature follows Manganelli et al. (1995) and subsequent updates. Voucher specimens were deposited in Manganelli collection, Dipartimento di Scienze Fisiche, della Terra e dell’Ambiente, Università di Siena (Italy). 
Two groups of explanatory variables (environmental and spatial) were calculated for each site and used to model land snail species richness and composition. The environmental properties of each site were quantified by three variables: 1) distance from city centre ("Dist_center") measured as linear distance from the city cathedral to the sampling site (Horsák et al. 2009); 2) distance from sea ("Dist_sea”) assessed as minimum linear distance from the site to the nearest point on the coastline; 3) vegetation cover ("Tree_cover"), ranging from 0 to $100 \%$ of total area of sampling site. Spatial variables were XY geographical coordinates and all the spatial structures at different scales detected by PCNM.

\section{Statistical analysis}

Observed and estimated species richness

$\alpha, \beta$ and $\gamma$ diversity were used to assess richness and diversity patterns at habitat and city level. $\alpha$ diversity was defined as species richness in each of the 24 sites and $\gamma$ diversity as species richness in each urban habitat or city. $\beta$ diversity, concerning species composition turnover within and between habitats and cities, was examined by the Simpson dissimilarity index ( $\beta$ sim; Baselga et al. 2007), which only considers dissimilarity due to spatial turnover, irrespective of species richness (Baselga 2010). Analysis of Variance (ANOVA) and Bonferroni p-value adjustment for multiple comparisons were used to test for statistically significant differences. The Chao2 richness estimator and its standard error Chao.se (Chao 1987) were also used to estimate the minimum asymptote of species richness for habitats and cities in order to detect the number of unseen or undetected species in relation to observed species richness and sampling efficiency.

Environmental and spatial effects on land snail assemblages: PCNM and Variation Partitioning

To evaluate the effects of environment and space on species composition, principal coordinate analysis of neighbour matrices (PCNM, Borcard et al. 2004) was used to detect spatial structure in the data. Compared to traditional multivariate trend-surface analysis, PCNM detects, decomposes and models any type of hidden spatial structure in the data, within the limits of sampling design (Borcard and Legendre 2002). It makes it possible to select the best linear combination of eigenvectors, maximizing correlation with the data and minimizing the number of vectors (Dray et al. 2006). We first computed a matrix of Euclidean distances among the 24 sites using the latitudes and longitudes of sampling sites. Before running PCNM, the data was detrended by regressing all variables against the geographical coordinates (X-Y), retaining residuals. The Euclidean distances were then truncated: PCNM is based on the assumption that the only meaningful spatial signals for plots are those circumscribed by neighbourhood sites (Dray et al. 2006). The truncation distance, which defines neighbourhood thresholds, is considered the maximum distance connecting all plots based on a minimum spanning tree criterion (Rangel et al. 2006). The give.thresh function in the spacemakerR package was used.

PCNM was performed on the modified (i.e. truncated) distance matrix to extract eigenvectors (PCNM variables) to use as new spatial explanatory variables. Since PCNM are orthogonal, each PCNM variable represents an independent spatial gradient. The higher the eigenvalue of a PCNM variable, the broader the spatial scale represented, while PCNM variables with low eigenvalues only explain small fractions of the total spatial structure and are related to finer spatial 
gradients (Duarte et al. 2012). The model selection procedure was based on multivariate extension of the AIC criterion using the ortho.AIC function in the SpacemakeR package. Six PCNM vectors obtained from the X-Y coordinates of each sampling site were then entered as explanatory variables for Redundancy Analysis (RDA) to account for the space effect on the urban land snail matrix. To reveal the urban gradient effect after removing the effect of space (i.e. pure spatial patterns that cannot be related to any measured variable + unmeasured spatially structured environmental variation), we computed the relative contribution of the three environmental variables (distance from city centre, distance from sea, \% vegetation cover) by partial RDA (pRDA) that excluded spatial influence from the community matrix.

Variation partitioning was later conducted to detect the fractions of total variance explained exclusively by the environmental predictors [a], by environment and space [b], exclusively by spatial variables [c] and finally by residual variation (Borcard et al. 1992; Peres-Neto et al. 2006), which can be ascribed to internal biological variation, survey error, or variables not included in the analysis (Legendre and Legendre 1998). Quantification of the variance components was based on the varpart function of the Vegan R package (Oksanen et al. 2016).

All multivariate statistical analysis based on Hellinger-transformed land snail presence/absence data was performed with RStudio version 0.99.473 (RStudio Team 2015).

\section{Results}

Observed and estimated species richness

Total land snail richness was 53 species (Table 1). Communities were dominated by Cornu aspersum and Xerotricha conspurcata present in 19 and 18 out of 24 sites, respectively, while rare species such as Howenwartiana howenwartii, Marmorana serpentina, Cepaea nemoralis and Vitrea etrusca occurred in 2 or 3 out of 24 sites. Some species are ranked as LC (Least Concern) in the IUCN Red List, while only three are alien (the Australasian Paralaoma servilis, the Sardo-Corsican Marmorana serpentina and the Mediterranean Deroceras invadens).

Numbers of land snail species found in sites ranged from 5 to 29 with a mean of 14 (Lososová et al. 2011: 0-21, mean 7.5). The lowest mean number of land snail species per site ( $\alpha$ diversity) was found in early successional sites (ESUC) and old city walls (WALLS) (9 and 13, respectively) while the highest mean $\alpha$ diversity was in wooded sites (WOOD) and urban gardens and parks (PARK) (17 and 16, respectively). The total number of species found in each habitat type ( $\gamma$ diversity) was lowest in early successional sites (E-SUC: 30) and increased in old city walls (WALLS: 31), reaching its highest values in wooded suburban areas (WOOD: 37) and parks (PARK: 38) (Fig. 2a). Across habitats, $\gamma$ diversity was correlated with mean $\alpha$ diversity $(r=0.94, p=0.05$ ). One-way ANOVA (df 3; F-value 2.793; Pvalue 0.067 ) revealed no significant difference among habitat types. $\beta$ diversity was highest in E-SUC, lowest in all the other habitats. This agrees with the findings of Lososová et al. (2011) (Fig. 3a). One-way ANOVA (df 3; F-value 12.25; P-value 2.87e-06) and Bonferroni p-value adjustment for multiple comparisons showed that E-SUC significantly differed with respect to all the other habitats in $\beta$ diversity values (E-SUC-PARK $\mathrm{p}=9.5 \mathrm{e}-05$; E-SUC-WALLS $\mathrm{p}=3.7 \mathrm{e}-$ 05; E-SUC-WOOD $\mathrm{p}=2.5 \mathrm{e}-05$ ). Pairwise $\beta$ diversity values between habitat types were: WALLS-PARK 0.16; WALLS-E-SUC 0.37; WALLS-WOOD 0.32; PARK-E-SUC 0.20; PARK-WOOD 0.19; E-SUC-WOOD 0.17.

The lowest mean $\alpha$ diversity in the cities was recorded in Grosseto (GR) and Arezzo (AR) (11 in both cases) while the highest was recorded in Siena (SI) (19). The total number of species found in each city ( $\gamma$ diversity) was lowest in 
244 Grosseto (29), higher in Arezzo (35) and highest in Siena (44) (Fig. 2b). Across cities, $\gamma$ diversity was not correlated with mean $\alpha$ diversity ( $r=0.84, \mathrm{p}>0.05$ ). After one-way ANOVA (df 2; F-value 6.439; P-value 0.007) and Bonferroni correction for multiple comparisons, the SI-GR and SI-AR pairs proved to be significantly different in $\alpha$ diversity (SIGR $p=0.014$; SI-AR $p=0.018$ ). Arezzo showed the highest internal $\beta$ diversity, while Grosseto and Siena showed similar values (Fig. 3b). After one-way ANOVA (df 2; F-value 9.739; P-value 0.0002) and Bonferroni p-value adjustment, the AR-GR and AR-SI pairs resulted to be significantly different in $\beta$ diversity values (AR-GR $\mathrm{p}=0.001$; AR-SI $\mathrm{p}=0.001$ ). Pairwise $\beta$ diversity values between cities were: SI-GR 0.17; SI-AR 0.14; AR-GR 0.38.

The minimum estimated Chao2 richness and its standard error Chao.se differed among habitat types and cities (Fig. 4a,b). However, a few species are missing: more or less all species were detected with a reasonable degree of certainty through sampling effort.

Environmental and spatial effects on land snail assemblages: PCNM and Variation Partitioning

Total species matrix variation (Table 2) can be portioned in four parts: (a) pure effects of space, (b) combined variation i.e. spatially structured environmental variation, (c) pure effects of environment, (d) residual variation (Borcard et al. 1992). In our data matrix, the total contribution of spatial structures $(a+b)$ accounted for $16 \%$ of community structure whereas the variation attributed solely to pure spatial patterns, i.e. patterns that cannot be related to any measured environmental variable, was 13\% (a). Environmental factors (c + b) are invoked to explain a higher portion of species matrix variation (22\%) than explained by spatial structures. Furthermore, almost all of this rather high variation (c) (19\%) is ascribed to the pure effect of environment, i.e. species-environment relationship associated with local environment, irrespective of space. The percentage of residual variation (d) was large: more than half the total variation remained unexplained, while only $3 \%$ of the explained variation was shared (b) between the two factors. All the variation components had a significant effect $(\mathrm{p}<0.05)$. Redundancy analysis (Fig. 5) detected significant effect in shaping urban land snail composition for two out of three local environmental variables, namely "distance from the city centre" and "vegetation cover". Papillifera papillaris was clearly negatively associated with Dist_center and was the most characteristic species of WALLS assemblages followed by Mediterranea hydatina, which was also negatively associated with Tree_cover; Hohenwartiana hohenwartii was most linked to E-SUC habitat type, Monacha parumcincta was clearly positively associated with Dist_center and Tree_cover, proving the most characteristic species of WOOD assemblages, while Deroceras invades and Cernuella virgata were associated with PARK habitat type.

\section{Discussion}

This study is the first to consider the influence of environment and spatial factors on urban land snail communities in southern Europe, and the insights it provides are unexpected. In terms of land snail total species richness, we recovered 53 species over our $100 \mathrm{~km}$ transect, compared to the 87 species recorded over a much larger transect ( $>1200 \mathrm{~km})$ in central Europe by Chytrý et al. (2012) and the 54 forest entities found in three well preserved forest areas of Tuscany (Benocci et al. 2015). These numbers suggest that urban environments may actually offer a range of different habitat and environmental conditions to land snails, thereby creating a sort of heterogeneous melting pot of unlimited ecological situations. Perhaps, the many species found in the assemblage posses a wide variety of ecological requirements, which even in urban environments allow them to find optimal conditions to adapt, flourish and spread, 
just as happens in naturalized areas. The various results collected in this study support this general interpretation and we discuss these results below in terms of our three main aims.

$\alpha, \beta$ and $\gamma$ diversity

Concerning habitat $\gamma$ diversity, we did not find a clear decreasing trend from more (WALLS and PARK) to less urbanized habitats (E-SUC and WOOD), but rather a homogeneous pattern with just a dip in proximity to early successional sites. These open sub-urban habitats are typically in city peripheries; many are highly disturbed, often close to busy roads or industrial settlements, and function as ecological corridors (or barriers?) to the open countryside or woods. On the other hand, city parks, public gardens and wooded patches proved to be genuine islands of biodiversity in the urban matrix, showing the highest values of both $\alpha$ and $\gamma$ diversity. This finding agrees with other research from which it emerged that parks were the most diverse urban habitat for several groups of organisms (Lososová et al. 2011). Pairwise species composition differences between habitats showed major $\beta$ diversity values, the highest difference being between WALLS and E-SUC habitats: PARK and WOOD shared a common more or less forested matrix, whereas WALLS and E-SUC showed the strongest differences in terms of ecological conditions and environmental heterogeneity. At city level, Siena had the richest $\alpha$ and $\gamma$ diversity: it is the greenest of the three cities, characterized by many well preserved wooded and green patches inside the urban core, also relatively less impacted by vehicular traffic and the effects of urbanization. These results overall imply the great diversity of conditions in urban environments, which is reflected by diversity patterns in the land snail assemblage.

Conservation status

The checklist did not include species in danger of extinction or threatened; xenodiversity was apparently very low and only three species (5.7\% of the total) were true aliens: Paralaoma servilis is a worldwide litter- and humus-dwelling invasive species, probably of Australasian origin (Manganelli et al. 2015); Deroceras invadens, probably of central Mediterranean origin, is an invasive species worldwide (Reise et al. 2011) and Marmorana serpentina, first reported from the city of Grosseto by the present research, occurs in Sardinia and Corsica and has been introduced into certain Tuscan cities (Livorno, Pisa, Siena) (Fiorentino et al. 2009). As regards the remaining species, at least two (Lehmannia melitensis, Papillifera papillaris) may also have been introduced by anthropochory. They are nearly always found in habitats at the edge of urban areas or used by man at some time in the past. Finally, vast open and built-up areas have probably facilitated colonization by potentially indigenous but originally less widespread synanthropic species, such as the slug Limacus flavus and land snails Xerotricha conspurcata, Eobania vermiculata and Cornu aspersum (Manganelli et al. 2015). Biotic homogenization therefore does not seem to have had remarkable ecological impact: the small Tuscan cities still maintain considerable $\beta$ diversity, both within and between study areas, despite the restricted geographical distance gradient. Thus they differ from other cosmopolitan urban areas in Europe where the introduction of invasive species, together with human-mediated biotic interchange, resulted in widespread floristic and faunistic homogenization (La Sorte et al. 2007; Ferenc et al. 2014). 
Our attempt to discover the processes underlying land snail community structure by partitioning the pure effects of "environment" and that of unmeasured factors (dispersal, biotic interactions, unmeasured environmental variables) that create spatial structure (called "space"), provided the most interesting findings. Environment and space can be equally important in shaping communities but their function should always be considered in relation to the dispersal capacity of the group in question (Heino 2013). The relative role of deterministic and stochastic aspects driving ecological metacommunities has been examined in different organisms in natural environments (e.g. oribatid mites, Caruso et al. 2012; oribatid mites and collembola, Ingimarsdóttir et al. 2012; microbial communities, Caruso et al. 2011; several groups of aquatic organisms, Padial et al. 2014, Rádková et al. 2014, Zhai et al. 2015) but few studies have concerned urban areas (spiders, bees and birds, Sattler et al. 2010; subaerial cyanobacteria and algae, vascular plants and land snails, Chytrý et al. 2012). According to general belief, high dispersers should be less influenced by spatial effects since they move more readily to suitable habitat than low dispersers and species are consequently sorted according to their ecological requirements (Martiny et al. 2006; Heino 2013). Conversely, weak dispersers are expected to show significant spatial structuring as a direct consequence of their low mobility while their distribution is often due to stochastic processes mediated by limited dispersal (Bell 2000; Hubbell 2001). Paradoxically, although land snails are widely recognised as having low mobility (Baur and Baur 1993), they proved to be most significantly shaped by pure and spatially independent environmental processes, which often turn out to be irrelevant since the environment is usually spatially structured by various ecological processes (Legendre and Fortin 1989). In other words, after removing the effect of space (i.e. pure spatial patterns that cannot be related to any measured variables + unmeasured spatially structured environmental variation), urban gradient turned out to be the main factor modelling land snail community structure.

Some exceptions to the rule were also found by Hájek et al. (2011), who described much stronger environmental than spatial structure in bryophytes but not in high dispersers such as diatoms in Western Carpathian fens, and similarly Astorga et al. (2012) confirmed a preponderant influence of niche-related factors rather than spatially limited dispersal in bryophytes and macroinvertebrates in Finnish streams. Sattler et al. (2010) first took urban environments seriously into account, observing higher environmental influence and weak spatial structure for spiders over a gradient of three Swiss cities. According to Sattler et al. (2010), this combination with traditionally limited dispersers may be a feature typical of urban areas, where high disturbance affecting the heterogeneous mosaic of urban habitat could inhibit establishment of well-defined spatial structures, selecting only the species able to adapt and coexist with human activities. Recent studies on land snail dispersal confirmed the possibility of long distance passive dispersal (Ożgo et al. 2016) so that human-mediated transport in urban environments may be the most reasonable explanation for the high pure environmental constraint detected in urban land snail data: molluscs can be passively dispersed, but only if environmental conditions are suitable do they establish and develop well defined assemblages. Diverse microhabitat conditions and small-scale habitat structures are in fact necessary conditions for mollusc diversification, assuming a suitable geological substratum (Cuttelod et al. 2011). The pure environmental contribution therefore suggests selection of species well adapted to man-made environments, while other species show random distributions, probably as a consequence of occasional dispersal events.

The hypothesis of stronger environmental effect was also confirmed by RDA analysis that showed four well structured and differentiated species assemblages at habitat level, as demonstrated by 95\% confidence ellipses (Fig. 5).

"Distance from the city centre" and "Vegetation cover" proved to be the environmental variables most significantly involved in explaining variation in species composition. With the exception of parks and gardens within the city limits, 
the greater the distance from the urban centre, the higher the vegetation density. It is well known that forest cover provides shelter for land snails under unfavourable conditions (Dedov and Penev 2004). This has strong implications for species richness since the richest urban habitats are generally those with the highest tree and vegetation cover values (PARK and WOOD in our study). At the same time different forest cover values work as ecological filters, selecting species that depend on different environmental conditions. It is true that poor assemblages with few species are usually more frequent close to city centres, due to the reduced frequency of natural habitat (Horsák et al. 2009), but although poor in terms of richness, these completely anthropogenic assemblages often consist of surprisingly unique entities: WALLS harbour extremely specialist species (e.g. Marmorana serpentina, Papillifera papillaris, Papillifera solida), that shelter in rock clefts and cracks, instead of in litter and vegetation. Furthermore, subterranean species living in the ground behind walls, such as Mediterranean hydatina, which proved to be typical species in WALLS assemblages, can be included in this habitat.

The response of local land snail assemblages to urbanisation cannot be described as a gradual and linear decline in species richness with proximity to the city centre (Horsák et al. 2009), but rather as a clear change in species composition through selection/adaptation to different ecological conditions, presumably after passive human-mediated dispersal.

This significant environmental effect, reflecting niche processes as well as environmental filtering, is an interesting result since a strong spatially independent environmental constraint has never previously been detected for organisms limited by low dispersal within the urban matrix. This finding suggests the effect of human-mediated transport in enhancing the dispersal capacity of organisms normally considered to have low mobility. However, the snails would not become established in the absence of suitable microhabitat conditions. In particular, two urban environmental variables were the main constraints shaping urban land snail communities, namely vegetation cover and distance from the city centre. The detection of a pure spatially independent environmental effect has important conservation implications which go beyond the analysis of a single taxonomic group: irrespective of study area position, sampling in different cities would presumably show similar species assemblages explained by exactly the same dataset of environmental variables.

\section{Conclusion}

In conclusion, urban environments can show high land snail richness, like natural areas; species richness does not show a clear inverse trend in relation to urbanization of habitats, but rather a homogeneous pattern. While parks prove to be real islands of biodiversity inside the urban patchwork in terms of species composition, only urban environments such as old city walls provide ideal environments for many specialist species with particular ecological requirements (i.e. carbonate rocks, shaded walls rich in calcium and moist refuges).

Although the transect we studied was only $100 \mathrm{~km}$, the gradient explained an higher amount of variation to that obtained by Lososová et al. (2011) and Chytrý et al. (2012) with transects of more than $1200 \mathrm{~km}$ in central Europe. In addition to demonstrate the wealth of diversity patterns offered by the Mediterranean area and especially the Italian peninsula, this finding furnishes a proof of the necessity of combining traditional visual search with debris and leaf litter collection. Indeed, leaf litter collections allowed quantification of small and micro-snails.

City study areas host rather heterogeneous species assemblages where biotic homogenization seems very low: only three out of 53 species were true alien species (Paralaoma servilis, Marmorana serpentina and Deroceras invadens). 
After detecting and removing the influence of spatial structures, the effect of urban gradient turned out to be the principal component structuring urban land snail assemblages. In particular, "Distance from the city centre" and

409 "Vegetation cover" were the environmental variables that explained most of the variation in species composition. This 410 finding shows the importance of environmental factors, possibly because of a combination of niche and environmental 411 filtering at local level for organisms with low mobility, which are usually structured by spatial constraints. It also 412 suggests new urban scenarios with major ecological and conservation implications for other invertebrate groups: inside 413 this complex urban matrix, even intensively managed habitats could support particular assemblages as results of unique 414 interactions between species and environment at local scale. This provides guidance for managers to set priorities in 415 management strategies that include habitat conservation at local scale. 
Angold PG, Sadler JP, Hill MO, Pullin A, Rushton S, Austin K, Small E, Wood B, Wadsworth R, Sanderson R, Thompson K (2006) Biodiversity in urban habitat patches. Sci Total Environ 360(1):196-204. doi:10.1016/j.scitotenv.2005.08.035

Aronson MF, La Sorte FA, Nilon CH, Katti M, Goddard MA, Lepczyk CA, Warren PS, Williams NSG, Cilliers S, Clarkson B, Dobbs C, Dolan R, Hedblom M, Klotz S, Louwe Kooijmans J, Kühn I, MacGregor-Fors I, McDonnell M, Mörtberg U, Pyšek P, Siebert S, Sushinsky J, Werner P, Winter M (2014) A global analysis of the impacts of urbanization on bird and plant diversity reveals key anthropogenic drivers. P Roy Soc Lond B Bio 281(1780):20133330. doi:10.1098/rspb.2013.3330

Astorga A, Oksanen J, Luoto M, Soininen J, Virtanen R, Muotka T (2012) Distance decay of similarity in freshwater communities: do macro-and microorganisms follow the same rules? Global Ecol Biogeogr 21(3):365-375. doi:10.1111/j.14668238.2011.00681.x

Baldock KC, Goddard MA, Hicks DM, Kunin WE, Mitschunas N, Osgathorpe LM, Potts SG, Robertson KM, Scott AV, Stone GN, Vaughan IP, Memmott J (2015) Where is the UK's pollinator biodiversity? The importance of urban areas for flower-visiting insects. P Roy Soc Lond B Bio 282(1803):20142849. doi:10.1098/rspb.2014.2849

Barratt BI, Dickinson KJ, Freeman C, Porter S, Johnstone PD, Wing J, Heezik Y (2015) Biodiversity of Coleoptera and other invertebrates in urban gardens: a case study in a New Zealand city. Insect Conserv Diver 8(5):428-437. doi:10.1111/icad.12120

Baselga A (2010) Partitioning the turnover and nestedness components of beta diversity. Global Ecol Biogeogr 19(1):134-143. doi: 10.1111/j.1466-8238.2009.00490.x

Baselga A, Jiménez-Valverde A, Niccolini G (2007) A multiple-site similarity measure independent of richness. Biol Letters 3(6):642-645. doi:10.1098/rsbl.2007.0449

Baur A, Baur B (1993) Daily movement patterns and dispersal in the land snail Arianta arbustorum. Malacologia 35:89-98

Bell G (2000) The distribution of abundance in neutral communities. Am Nat 155(5):606-617. doi:10.1086/303345

Beninde J, Veith M, Hochkirch A (2015) Biodiversity in cities needs space: a meta-analysis of factors determining intra-urban biodiversity variation. Ecol Lett 18(6):581-592. doi:10.1111/ele.12427

Benocci A, Bacaro G, Manganelli G (2015) Local and regional scale biodiversity patterns of forest snail assemblages in Tuscany (central Italy). Community Ecol 16(2):147-155. doi:10.1556/168.2015.16.2.2

Beumer C, Martens P (2015) Biodiversity in my (back) yard: towards a framework for citizen engagement in exploring biodiversity and ecosystem services in residential gardens. Sustain Sci 10(1):87-100. doi:10.1007/s11625-014-0270-8

Borcard D, Legendre P (2002) All-scale spatial analysis of ecological data by means of principal coordinates of neighbour matrices. Ecol Model 153:51-68. doi:10.1016/S0304-3800(01)00501-4

Borcard D, Legendre P, Avois-Jacquet C, Tuomisto H (2004) Dissecting the spatial structure of ecological data at multiple scales. Ecology 85:1826-1832. doi: 10.1890/03-3111

Borcard D, Legendre P, Drapeau P (1992) Partialling out the spatial component of ecological variation. Ecology 73(3):1045-1055. doi:10.2307/1940179

Cadenasso ML, Pickett ST, Schwarz K (2007) Spatial heterogeneity in urban ecosystems: reconceptualizing land cover and a framework for classification. Front Ecol Environ 5(2):80-88. doi:10.1890/15409295\%282007\%295\%5b80:SHIUER\%5d2.0.CO;2

Cameron RAD, Pokryszko BM (2005) Estimating the species richness and composition of land mollusc communities: problems, consequences and practical advice. J Conchol 38:529-547

Carrus G, Scopelliti M, Lafortezza R, Colangelo G, Ferrini F, Salbitano F, Agrimi M, Portoghesi L, Semenzato P, Sanesi G (2015) Go greener, feel better? The positive effects of biodiversity on the well-being of individuals visiting urban and peri-urban green areas. Landscape Urban Plan 134:221-228. doi:10.1016/j.landurbplan.2014.10.022

Caruso T, Chan Y, Lacap DC, Lau MC, McKay CP, Pointing SB (2011) Stochastic and deterministic processes interact in the assembly of desert microbial communities on a global scale. ISME J 5(9):1406-1413. doi:10.1038/ismej.2011.21

Caruso T, Taormina M, Migliorini M (2012) Relative role of deterministic and stochastic determinants of soil animal community: a spatially explicit analysis of oribatid mites. J Anim Ecol 81(1): 214-221. doi:10.1111/j.1365-2656.2011.01886.x

Chao A (1987) Estimating the population size for capture-recapture data with unequal catchability. Biometrics 43: 783-791. doi:10.2307/2531532

Chytrý M, Lososová Z, Horsák M, Uher B, Čejka T, Danihelka J, Fajmon K, Hájek O, Juřičková L, Kintrová Láníková D, Otŷpková Z, Řeho ̌̌ek V, Tichý L (2012) Dispersal limitation is stronger in communities of microorganisms than macroorganisms across Central European cities. J Biogeogr 39(6):1101-1111. doi:10.1111/j.1365-2699.2011.02664.x

Cuttelod A, García N, Abdul Malak D, Temple H, Katariya V (2008) The Mediterranean: a biodiversity hotspot under threat. In: J.-C. Vié, C. Hilton-Taylor and S.N. Stuart (eds). The 2008 Review of The IUCN Red List of Threatened Species. IUCN Gland, Switzerland

Cuttelod A, Seddon M, Neubert E (2011) European Red List of Non-marine Molluscs. Publications Office of the European Union, Luxembourg. https://portals.iucn.org/library/efiles/documents/RL-4-014.pdf. Accessed 16 June 2016 
Czech B, Krausman PR, Devers PK (2000) Economic Associations among Causes of Species Endangerment in the United States Associations reflect the integration of economic sectors, supporting the theory and evidence that economic growth proceeds at the competitive exclusion of nonhuman species in the aggregate. BioScience 50(7):593-601. doi:10.1641/00063568(2000)050[0593:E

Dedov I, Penev L (2004) Spatial variation in terrestrial gastropod communities (Gastropoda, Pulmonata) along urban-rural gradients in Sofia City, Bulgaria. In: Penev L, Niemelä J, Kotze J, Chipev N (eds) Ecology of the city of Sofia. Species and communities in an urban environment. Pensoft Publishers, Moscow, pp 307-318

Douglas DD (2011) Land snail species diversity and composition between different forest disturbance regimes in central and eastern Kentucky Forests. Dissertation, Eastern Kentucky University

Douglas DD, Brown DR, Pederson N (2013) Land snail diversity can reflect degrees of anthropogenic disturbance. Ecosphere, 4(2) art28. doi:10.1890/ES12-00361.1

Dray S, Legendre P, Peres-Neto PR (2006) Spatial modelling: a comprehensive framework for principal coordinate analysis of neighbour matrices (PCNM). Ecol Model 196(3):483-493. doi:10.1016/j.ecolmodel.2006.02.015

Duarte LD, Prieto PV, Pillar VD (2012) Assessing spatial and environmental drivers of phylogenetic structure in Brazilian Araucaria forests. Ecography 35(10):952-960. doi:10.1111/j.1600-0587.2011.07193.x

Ferenc M, Sedláček O, Fuchs R, Dinetti M, Fraissinet M, Storch D (2014) Are cities different? Patterns of species richness and beta diversity of urban bird communities and regional species assemblages in Europe. Global Ecol Biogeogr 23(4):479-489. doi:10.1111/geb.12130

Fiorentino V, Caruso T, Manganelli G, Giusti F (2009) Population dynamics of an urban population of the land snail Marmorana serpentina (Gastropoda: Pulmonata). Malacologia 51(1):01-209. doi:10.4002/040.051.0116

Fuller RA, Irvine KN, Devine-Wright P, Warren PH, Gaston KJ (2007) Psychological benefits of greenspace increase with biodiversity. Biol Letters 3(4):390-394. doi:10.1098/rsbl.2007.0149

Grimm NB, Faeth SH, Golubiewski NE, Redman CL, Wu J, Bai X, Briggs JM (2008) Global change and the ecology of cities. Science 319:756-760. doi:10.1126/science.1150195

Güneralp B, Seto KC (2013) Futures of global urban expansion: uncertainties and implications for biodiversity conservation. Environ Res Lett 8(1):014025. doi:10.1088/1748-9326/8/1/014025

Hahs AK, McDonnell MJ, McCarthy MA, Vesk PA, Corlett RT, Norton BA, Clemants SE, Duncan RP, Thompson K, Shwartz MW, Williams NS (2009) A global synthesis of plant extinction rates in urban areas. Ecol Lett 12(11):1165-1173. doi:10.1111/j.1461-0248.2009.01372.x

Hájek M, Roleček J, Cottenie K, Kintrová, K., Horsák, M., Poulíčková, A., Hájková P, Fránková, Dítě, D. (2011) Environmental and spatial controls of biotic assemblages in a discrete semi-terrestrial habitat: comparison of organisms with different dispersal abilities sampled in the same plots. J Biogeogr 38(9):1683-1693. doi:10.1111/j.1365-2699.2011.02503.x

Hartop EA, Brown BV, Disney RHL (2015) Opportunity in our Ignorance: Urban Biodiversity Study Reveals 30 New Species and One New Nearctic Record for Megaselia (Diptera: Phoridae) in Los Angeles (California, USA). Zootaxa 3941(4):451-484. doi:10.11646/zootaxa.3941.4.1

Heino J (2013) Does dispersal ability affect the relative importance of environmental control and spatial structuring of littoral macroinvertebrate communities? Oecologia 171(4):971-980. doi:10.1007/s00442-012-2451-4

Horsák M, Juřičková L, Kintrová K, Hájek O (2009) Patterns of land snail diversity over a gradient of habitat degradation: a comparison of three Czech cities. Biodivers Conserv. doi: 18:3453-3466. 10.1007/s10531-009-9654-y

Hubbell SP (2001) The unified neutral theory of biodiversity and biogeography (MPB-32) (Vol. 32). Princeton University Press

Ingimarsdóttir M, Caruso T, Ripa J, Magnúsdóttir ÓB, Migliorini M, Hedlund K (2012) Primary assembly of soil communities: disentangling the effect of dispersal and local environment. Oecologia 170(3):745-754. doi:10.1007/s00442-012-2334-8

La Sorte FA, McKinney ML, Pyŝek P (2007) Compositional similarity among urban floras within and across continents: biogeographical consequences of human-mediated biotic interchange. Glob Change Biol 13:913-921. doi:10.1111/j.1365 2486.2007.01329.x

Legendre P, Fortin MJ (1989) Spatial pattern and ecological analysis. Vegetatio 80(2):107-138. doi:10.1007/BF00048036

Legendre P, Legendre L (1998) Numerical Ecology. Elsevier, Amsterdam.

Legendre P, Mi X, Ren H, Ma K, Yu M, Sun IF, He F (2009) Partitioning beta diversity in a subtropical broad-leaved forest of China. Ecology 90(3):663-674. doi:10.1890/07-1880.1

Lockwood JL (2004) How do biological invasions alter diversity patterns? In: Lomolino MV, Heaney LR (eds) Frontiers of Biogeography: New Directions in the Geography of Nature, Sinauer, Sunderland, MA, pp 297-309

Lososová Z, Horsák M, Chytrý M, Čejka T, Danihelka J, Fajmon K, Hájek O, Juřičková L, Kintrová K, Láníková D, Otýpková Z, Řehořek V, Tichý L (2011) Diversity of Central European urban biota: effects of human-made habitat types on plants and land snails. J Biogeogr 38:1152-1163. doi:10.1111/j.1365-2699.2011.02475.x

Lydeard C, Cowie RH, Ponder WF, Bogan AE, Bouchet P, Clark SA, Cumming KS, Frest TJ, Gargominy O, Herbert DG, Hershler R, Perez KE, Roth B, Seddon M, Strong E, Thompson FG (2004) The global decline of nonmarine mollusks. BioScience 54(4):321-330. doi:10.1641/0006-3568(2004)054[0321:T 
Mänd R, Tilgar V, Leivits A (2000) Calcium, snails, and birds: a case study. Web Ecology 1(1):63-69. doi:10.5194/we-1-63-2000

Manganelli G, Benocci A, Giusti F (2014) Chiocciole e lumache dell’Arcipelago Toscano. I Quaderni del Parco, volume 4.

Manganelli G, Bodon M, Favilli L, Giusti F (1995) Gastropoda Pulmonata. In: A. Minelli, S. Ruffo and S. La Posta (eds), Checklist delle specie della fauna d'Italia, 16. Edizioni Calderini, Bologna, pp 1-60

Martiny JBH, Bohannan BJ, Brown JH, Colwell RK, Fuhrman JA, Green JL, Horner-Devine MC, Kane M, Adams Krumins J, Ruske CR, Morin PJ, Naeem S, Øvreås L, Reysenbach A, Smith VH, Staley JT (2006) Microbial biogeography: putting microorganisms on the map. Nat Rev Microbiol 4(2):102-112. doi:10.1038/nrmicro1341

Maurer U, Peschel T, Schmitz S (2000) The flora of selected urban land-use types in Berlin and Potsdam with regard to nature conservation in cities. Landscape Urban Plan 46(4):209-215. doi:10.1016/S0169-2046(99)00066-3

McKinney ML (2002) Urbanization, Biodiversity, and Conservation The impacts of urbanization on native species are poorly studied, but educating a highly urbanized human population about these impacts can greatly improve species conservation in all ecosystems. BioScience 52(10):883-890. doi:10.1641/0006-3568(2002)052[0883:UBA

McKinney ML (2006) Urbanization as a major cause of biotic homogenization. Biol Conserv 127(3):247-260. doi:10.1016/j.biocon.2005.09.005

McKinney ML (2008) Effects of urbanization on species richness: a review of plants and animals. Urban Ecosyst 11(2):161-176. doi:10.1007/s11252-007-0045-4

Menez A (2007) A new approach to studying and sampling land molluscs: habitat structure and the effects of scale on land molluscs. J Conchol 39:321-327

Mimouni EA, Pinel-Alloul B, Beisner BE (2015) Assessing aquatic biodiversity of zooplankton communities in an urban landscape. Urban Ecosyst 18(4):1353-1372. doi:10.1007/s11252-015-0457-5

Mitchell R, Popham F (2008) Effect of exposure to natural environment on health inequalities: an observational population study. The Lancet, 372(9650):1655-1660. doi:10.1016/S0140-6736(08)61689-X

Oksanen J, Blanchet FG, Kindt R, Legendre P, Minchin PR, O'Hara RB, Simpson GL, Solymos P, Stevens MHH, Wagner HH (2016) vegan: Community Ecology Package. R package version 2.3-3. http://CRAN.R-project.org/package=vegan

Ożgo M, Örstan A, Kirschenstein M, Cameron R (2016) Dispersal of land snails by sea storms. J Mollus Stud 82(2):341-343. doi:10.1093/mollus/eyv060

Padial AA, Ceschin F, Declerck SA, De Meester L, Bonecker CC, Lansac-Tôha FA, Rodrigues LC, Train S, Velho LFM, Bini LM (2014) Dispersal ability determines the role of environmental, spatial and temporal drivers of metacommunity structure. PloS one, 9(10):e111227. doi:10.1371/journal.pone.0111227

Pauget B, Gimbert F, Coeurdassier M, Crini N, Pérès G, Faure O, Douay F, Richard A, Grand C, de Vaufleury A (2013) Assessing the in situ bioavailability of trace elements to snails using accumulation kinetics. Ecol Indic 34:126-135. doi:10.1016/j.ecolind.2013.04.018

Paul MJ, Meyer JL (2008) Streams in the urban landscape. In: Marzluff JM, Shulenberger E, Endlicher W, Alberti M, Bradley G, Ryan C, Simon U, ZumBrunnen C (eds) Urban ecology Springer, US, pp. 207-231

Peres-Neto PR, Legendre P, Dray S, Borcard D (2006) Variation partitioning of species data matrices: estimation and comparison of fractions. Ecology 87(10):2614-2625. doi:10.1890/0012 9658(2006)87[2614:VPOSDM]2.0.CO;2

Rádková V, J. Bojková V, Křoupalová J, Schenková V, Syrovátka, Horsák M (2014) The role of dispersal mode and habitat specialization in metacommunity structuring of aquatic macroinvertebrates at isolated spring fens. Freshwater Biol 59:22562267. doi:10.1111/fwb.12428

Rangel TFL, Diniz-Filho JAF, Bini LM (2006) Towards an integrated computational tool for spatial analysis in macroecology and biogeography. Glob Ecol Biogeogr 15(4):321-327. doi:10.1111/j.1466-822X.2006.00237.x

Régnier C, Fontaine B, Bouchet P (2009) Not knowing, not recording, not listing: numerous unnoticed mollusk extinctions. Conserv Biol 23(5):1214-1221. doi:10.1111/j.1523-1739.2009.01245.x

Reise H, Hutchinson J, Schunack S, Schlitt B (2011) Deroceras panormitanum and congeners from Malta and Sicily, with a redescription of the widespread pest slug as Deroceras invadens n. sp. Folia Malacol 19(4):201. doi:10.2478/v10125-011$0028-1$

Rota E, Barbato D, Ancora S, Bianchi N, Bargagli R (2016) Papillifera papillaris (O.F. Müller), a small snail living on stones and monuments, as indicator of metal deposition and bioavailability in urban environments. Ecol Indic 69: 360-367 doi:10.1016/j.ecolind.2016.04.024

RStudio Team (2015) RStudio: Integrated Development for R. RStudio, Inc., Boston, MA URL http://www.rstudio.com/

Sattler T, Borcard D, Arlettaz R, Bontadina F, Legendre P, Obrist MK, Moretti M (2010) Spider, bee, and bird communities in cities are shaped by environmental control and high stochasticity. Ecology 91(11):3343-3353. doi:10.1890/09-1810.1

Seddon MB (1998) Red Listing for Molluscs: a tool for Conservation? J Conchol (2):27-44.

Taylor L, Hochuli DF (2015) Creating better cities: how biodiversity and ecosystem functioning enhance urban residents' wellbeing. Urban Ecosyst 18(3):747-762. doi:10.1007/s11252-014-0427-3

ter Braak CJ (1986) Canonical correspondence analysis: a new eigenvector technique for multivariate direct gradient analysis. Ecology 67(5):1167-1179. doi:10.2307/1938672 
United Nations (2014) World Urbanization Prospects: The 2014 Revision. United Nations Department of Economic and Social Affairs/Population Division, (ST/ESA/SER.A/352)

United Nations Environment Programme (UNEP) (2005) Ecosystems and Biodiversity The Role of Cities. https://esa.un.org/unpd/wup/Publications/Files/WUP2014-Report.pdf. Accessed 20 June 2016

Viviani VR (2001) Fireflies (Coleoptera: Lampyridae) from Southeastern Brazil: habitats, life history, and bioluminescence. Ann Entomol Soc Am 94(1):129-145. doi:10.1603/0013-8746(2001)094[0129:FCLFSB]2.0.CO;2

Wang Y, Fu X, Lei C, Jeng ML, Nobuyoshi O (2007) Biological Characteristics of the Terrestrial Firefly Pyrocoelia pectoralis (Cleoptera: Lampyridae). Coleopts Bull 61(1):85-93

Williams NS, Schwartz MW, Vesk PA, McCarthy MA, Hahs AK, Clemants SE, Corlett RT, Duncan RP, Norton BA, Thompson K, McDonnell MJ (2009) A conceptual framework for predicting the effects of urban environments on floras. J Ecol 97(1):4-9. doi:10.1111/j.1365-2745.2008.01460.x

Zhai M, Nováèek O, Výravský D, Syrovátka V, Bojková J, Helešic J (2015) Environmental and spatial control of ostracod assemblages in the Western Carpathian spring fens. Hydrobiologia 745(1):225-239. doi:10.1007/s10750-014-2104-1 
Table captions

Table 1 Land snail species in three cities (Grosseto, Siena, Arezzo) and total number of species in each urban area

Table 2 Summary of variation partitioning constituents for urban land snails obtained by partial RDAs with environmental and spatial data as predictors

Fig. $2 \alpha$ diversity (species richness per site, box and whiskers) and $\gamma$ diversity (total number of species, numbers outside box and whiskers) in habitat types (a, on the left) and cities (b, on the right). Different letters denote significant differences between groups (ANOVA with Bonferroni p-value adjustment, $\mathrm{p}<0.05$ )

\section{Figure captions}

Fig. 1 Map of study area and location of sampling sites (red dots) in each city

Fig. 3 Box plots of Simpson $\beta$ diversity in habitat types (a, on the left) and cities (b, on the right). Different letters denote significant differences between groups (ANOVA with Bonferroni $\mathrm{p}$-value adjustment, $\mathrm{p}<0.05$ )

Fig. 4 Bar plots of $\gamma$ diversity in habitat types ( $a$, on the left) and cities (b, on the right) showing the minimum estimated richness Chao2 and its standard error Chao.se

Fig. 5 Ordination plots of RDA showing the pure effect of environmental variables (arrows in blue) shaping land snail communities. Above the entire ordination diagram while below we zoomed in to focus on a section of the ordination plot. The species numbers (s1, s2, ..., s53) match the numerical order in Table 1, while row numbers (row1, row2, ...row24) match the 24 sampling sites. Ellipses show the 95\% confidence intervals associated with each habitat type 